\title{
WIDER
}

World Institute for Development Economics Research

\author{
Discussion Paper No. 2001/59
}

\section{Growth, Economic Development and Structural Transition in Small Vulnerable States}

\author{
Robert Read*
}

August 2001

\begin{abstract}
This paper reviews the critical theoretical and policy issues relating to growth, economic development and structural transition in small states. The paper discusses alternative perspectives on small size and highlights the salient characteristics which give rise to their economic sub-optimality. The theoretical and empirical relationship between size and growth is reviewed, including recent inferences relating to structural transition and comparative advantage in small states. This discussion derives several insights from endogenous growth theory and highlights the critical role of available endogenous policy options, particularly with respect to trade and its implications for the process of growth and development. The discussion of vulnerability touches upon methodological and data issues relating to measurement, provides a critique of alternative indices and the impact of vulnerability in small states.
\end{abstract}

Keywords: small states, micro-states, growth, vulnerability, development, policy strategies

JEL classification: O40, O56, O57

Copyright (c) UNU/WIDER 2001

* Department of Economics, University of Lancaster, r.read@lancaster.ac.uk

This study has been prepared within the UNU/WIDER project on Globalization and the Obstacles to the Successful Integration of Small Vulnerable Economies which is directed by Dr Mansoob Murshed.

UNU/WIDER gratefully acknowledges the financial contribution to the project by the Ministry for Foreign Affairs of Finland. 
The paper argues that the growth success of many small states in spite of the inherent adverse effects of size, including vulnerability, owes much to effective specialisation and the quality of endogenous policy-making. Vulnerability to exogenous shocks has the capacity to severely destabilise the growth process, particularly of small developing states, but further work is required in refining the quantification and magnitude of these effects.

\section{Acknowledgements}

This is a substantially revised version of a paper first presented at the WIDER Workshop on Globalization and the Obstacles to the Successful Integration of Small Vulnerable Economies held at the World Institute for Development Economics Research, United Nations University, Helsinki Finland 18th to 21st May 2000. The author is grateful to Mansoob Murshed for his guidance and comments, the comments of a many participants at the Conference and those of an anonymous referee. 


\section{The conceptualisation and measurement of small size}

The analytical literature on small states covers a wide range of issues of interest to a number of disciplines. It is therefore hardly surprising that while most analyses exhibit some degree of consensus regarding the definition of small states and their inherent characteristics, there has only been limited methodological consistency, even within particular disciplines. This has resulted in a confusing profusion of conflicting policy implications in the literature. The primary methodological problem in the literature has been the use of a consistent conceptualisation, and therefore measurement, of small size. Many studies choose those measures which encompass particular facets of small size and, in turn, determine the identification and implications of the critical characteristics of smallness.

\subsection{Nomenclature issues}

There is some degree of inconsistency in terms of the basic nomenclature of small states evident in the literature. The World Bank classification distinguishes between 'small states' per se and 'micro-states' which are smaller. Further, several studies use additional or alternative classifications such as 'mini-states' and 'very small states'. This inconsistency is partly a reflection of the evolution of terminology in the developing economic literature but also raises an important methodological question concerning the existence of critical size thresholds. The term 'small states' is utilised consistently here to refer specifically to the concept of economic smallness.

\subsection{The measurement of small size}

There are four principal economic and geographic indicators according to which small size can be measured; population, GDP, geographical area and the terms of trade, each of which is considered in turn below.

\subsubsection{Population size}

This is the most commonly used indicator of country size, primarily because of the widespread availability of basic population data, easily comprehensible magnitudes and the ease with which simple thresholds can be imposed. In economic terms, population data is also useful because it represents a crude proxy for the size of both the domestic market and the local labour force.

Early studies of small economies utilise critical population thresholds of between 10 and 15 million (eg, Kuznets, 1960; Chenery and Taylor, 1968; Chenery and Syrquin, 1975). The steady emergence of new and smaller states however, has resulted in the progressive lowering of this threshold in many later studies. Contrary to this trend, a threshold of 20 million was proposed by UNIDO, based upon a hierarchical clustering algorithm grouping countries according to population (UNIDO, 1979). In the early 1970s, the principal international institutions such as the World Bank adopted a threshold of 1 million, which remains the most commonly used indicator of small size. 
Several studies have introduced further sub-divisions to distinguish between 'small states', 'mini-states' and 'micro-states'. Hein's review of the population thresholds used in the empirical literature distinguishes between 'high' cut-off points (greater than 1 million), 'medium' cut-off points (at 1 million) and 'low; cut-off points (less than 1 million) (Hein, 1985).

The critical methodological problem with the imposition of specific size thresholds is that population is a continuous variable such that the use of arbitrary structural breaks cannot be justified on theoretical grounds. Instead, several studies have therefore attempted to identify natural breaks in the distribution of population between states, the first being Taylor (1969). A natural break above 2.9 million (Singapore) has provided the basis for extensive recent empirical work by Armstrong and Read (Armstrong et al, 1996, 1998; Armstrong and Read, 1998, 2000). The principal drawback with this approach however, is that any natural breaks are unlikely to be robust over time given differential rates of population growth.

Some other non-economic studies have been more concerned with particular characteristics of population rather than absolute numbers: for example, anthropological (Smith, 1967; Pitt, 1985); demographic (Ward, 1967, 1982; Caldwell et al, 1980; Ahlburg, 1986) and political (Kohr, 1957).

\subsubsection{Gross domestic/national product (GDP/GNP)}

These are more normally used as an official measure of the aggregate value of economic activity undertaken either within a state (GDP) or by a state (GNP). GDP/GNP measures have also been used as a size criterion because they indicate the total magnitude of economic activity associated with a particular state and so provide another means of gauging market size and the potential for scale economies.

GDP/GNP measures suffer from several specification problems however. States may have similar levels of GDP/GNP but differ significantly in their populations and therefore per capita incomes. Normalising for population produces an indicator of relative economic development (GDP/GNP per capita) but not necessarily of size. Further, it is difficult to distinguish between separate, but possibly related, explanations of low GDP/GNP; a dearth of economic activity and small size. The aggregate level of economic activity is also prone to annual fluctuation since it is determined by domestic and international market conditions. Finally, GDP/GNP, like population, is also a continuous variable which requires arbitrary breaks to be imposed without theoretical basis.

GDP/GNP measures are therefore of little use as a general stand-alone criterion of smallness. A low level of aggregate economic activity in many developing countries (LDCs), particularly the least developed (LLDCs) however, is regarded as a critical issue in the economic development literature. The low volume of GDP/GNP in both LDCs and states with small populations suggests that there may be some similarities in the tasks facing them. This suggests that the economic analysis of LDCs and small states may therefore generate insights of mutual value to both groups. 


\subsubsection{Geographic area}

Geographic area is an indicator of land availability as well as a proxy for natural resource endowment and can be modified to incorporate topographical characteristics, notably cultivable area (eg, Jalan, 1982; Lloyd and Sundrum, 1982). Developments in the Law of the Sea has meant that some island states have gained sovereignty Economic Exclusion Zones (EEZs) which are far greater than their actual land areas, for example Kiribati (see Table 7.2 in Dommen and Hein, 1985).

The problem with geographic area as a measure of economic size, whether in terms of land, cultivable area or total EEZ, is that it only provides sufficient information for a crude proxy for potential resource endowments. It has therefore been used to complement demographic data to provide an indicator of population density, raising a range of economic additional issues, including demographic dispersion (Dommen, 1980, 1985).

\subsubsection{The terms of trade}

The net barter terms of trade refers to the relative price of a country's imports and exports in international markets. The inability of a country to influence its terms of trade because it has no international market power is a critical assumption underlying analysis of 'small open economies' in orthodox economic theory. Small economic size is thus equated to the absence of market power but in actuality is used to refer to relatively large advanced European industrial economies. The most original and substantive contribution to the economic literature on small size was primarily concerned with countries with populations of between 10 and 15 million (Robinson, 1960).

The post-war growth of world trade together with widespread industrialisation has made international markets increasingly competitive such that very few countries are able to influence their own terms of trade apart from the very largest, such as the United States and Japan. Further, the influence of countries with similar populations, income levels and production structures over their terms of trade may be very different because import and export prices are determined by market conditions, market structure, access to technology and the elasticities of demand, supply and income. The composition and characteristics of trade, particularly with respect to the export of differentiated manufactures, is therefore critically important. The required size threshold of the terms of trade definition is extremely large and therefore has little to offer the analysis of small states.

\subsubsection{Composite measures of size}

Several studies have attempted to capture different aspects of small size by creating composite measures of two or more variables. Taylor calculates the medians of the frequency distributions of the population, GDP/GNP and area variables to establish a size threshold and uses cluster techniques to allocate countries to particular groups (Taylor, 1969). Using the same size variables, an equal-weighted composite country size index using medians of is developed by Jalan (1982) while Downes uses principal components analysis to derive a weighted index of country size (Downes, 1988). Unfortunately, none of these composite measures are easily conceptualised, they are also subject to periodic fluctuation and their general results do not differ greatly from the population variable on its own. 


\subsubsection{Size measures of smallness: a critique}

The four principal size measures each capture different aspects of smallness and have different implications while the composite measures make use of the first three variables but provide little additional useful information. All of the size variables are continuous and arbitrary breaks tend to be imposed without any underlying theoretical justification. Population and GDP/GNP measures are both prone to change, whether predictable or not, such that any threshold only provides a 'snapshot' for cross-section analysis. While usually unchanging, geographic area does not really provide a real indication of the nature and extent of economic activity in a particular state. A lack of influence over the terms of trade is too general to be applied specifically to small economies. This suggests that, in terms of embodying both information content and ease of conceptualisation, population is the best available measure of size. It is also apparent that natural breaks and clusters do occur and can be used to group states. Nevertheless, there is no theoretical justification underlying the selection of any particular population size threshold.

The use of any of these variables as a measure of size is therefore open to criticism because of their lack of precision. It has also been argued that they fail to capture the underlying diversity of the states being considered (Wood, 1967; Hein, 1985), including the people concerned (Kohr, 1957; Schumacher, 1973). Socio-economic indicators such as health, education and income distribution as well as factors such as religion, ethnicity, linguistic, cultural, institutional and historical tradition may all have a critical role. These approaches are highly dependent upon rich economic and social data sets and are therefore very severely hampered by the scarcity of harmonised data series for all except the most basic economic data such as population and area in many small states and LDCs. The choice of size measure is therefore critically determined by the limited availability of data. The statistical problems associated with the lack of data and disparate data sets for analysing small states is discussed extensively elsewhere (see Armstrong et al, 1996, 1998).

\subsection{Islandness}

A significant part of the literature on small states concentrates upon island and archipelagic (multiple island) states rather than small states in general. Islandness has often been treated as the critical determinant factor, primarily because a significant proportion of small states are also island or archipelagic states, and this has caused some analytical confusion. Islandness certainly creates additional challenges, particularly relating to isolation, which may be compounded by small size. The fixation of many studies with islandness however, has meant that the problems of many small landlocked states have tended to be overlooked

The concentration upon islandness to the exclusion of small land-locked and littoral states suggests that the pure impact of small size may have been somewhat misspecified. Methodologically, small island states are a sub-set of small states in general. While islandness has been argued to be irrelevant (Selwyn, 1980), a consensus is emerging that many of the issues encountered by small island states are similar to those of smallness in general (Dommen, 1980; Shand, 1980; Dolman, 1985; Armstrong and Read, 1995, 1998, 2000; Armstrong et al, 1996, 1998; Briguglio, 1995). The intention here is to identify the critical issues relating to small states in general, regardless of their 
topography, and to consider specific issues relating to islands (referred to as nissology in McCall, 1996) where relevant.

\subsection{Political and economic sovereignty}

The economic analysis of the implications of small size raises critical issues with respect to the meaning of sovereignty. The concept of political sovereignty is straightforward in that the 1949 United Nations Charter sets out four necessary criteria for defining an independent state: a permanent population; a defined territory; a representative government; and the capacity to engage in external relations. The implications of these criteria have become entangled in conflict between two important UN principles, the right of independence/self-determination and of territorial integrity (UNITAR, 1969; de Smith, 1970; discussed extensively in Bartmann and Tyrell, 1998; Bartmann, 1999). The former applies solely to previously colonised territories while the latter applies generally, creating a logical inconsistency leading to a number of anomalies.

Political sovereignty however, is not a simple binary variable but is rather a discrete scale (Schaffer, 1975) ranging from full sovereignty under the UN Charter to relative autonomy in regions of larger states. This includes autonomous self-governing territories, trust territories, colonies, dependencies, possessions and territories. Differences in political sovereignty between states, territories and regions therefore are, at the margin, extremely fine and the fundamental characteristic of a sovereign state is the absence of a recognised legal claim of ownership on its territory by another state. Eschewing this legal distinction, political sovereignty is thus a non-linear variable with discrete intervals.

The concept of economic sovereignty is primarily concerned with the effective level of responsibility for economic policy formulation and implementation rather than ultimate territorial ownership. Economic sovereignty therefore relates specifically to autonomy over revenue-raising, primarily via taxation, expenditure, the regulatory environment and the determination of monetary, fiscal, trade and exchange rate policies. De jure economic sovereignty however, does not necessarily imply de facto economic policy autonomy given the constraints on small states (Read, 1995).

The distinction between political and economic sovereignty has generally been ignored in the literature on small states although much current work now refers to small jurisdictions. The concern here is with the economic implications of small size so that the critical unit of analysis is those territorial entities which possess economic sovereignty (Selwyn, 1980; Jalan, 1982; Lloyd and Sundrum, 1982; Armstrong and Read, 1995, 1998,2000; Armstrong et al, 1996, 1998). The substantive economic difference between small politically sovereign states, territories and the regions of larger states however, remains the potential of the latter two groups to receive fiscal transfers from the metropolitan state, whether or not they actually occur (see Armstrong and Read, 2000). The inclusion of a wide range of territories and regions which enjoy a considerable degree of economic autonomy and thus resemble small politically sovereign states has added analytical benefits in that it also widens the feasible statistical data set. 


\subsection{The identification and classification of small states}

The indicators of small size discussed in this Section facilitate the identification and classification of the potential set of small states presented in Table 1. These states are selected on the basis of four criteria: population, GDP/GNP, islandness and territorial economic sovereignty. Not surprisingly, there is some degree of overlap between these criteria. The intention of the Table is, in the first instance, to make use of the broadest possible thresholds for each indicator so as to maximise its inclusiveness. All states, including territories and autonomous regions of larger states, are considered so as to capture economic as opposed to political sovereignty. Initial selection is made on the basis of a population threshold of 3 million, with Singapore as the upper limit, and/or a low absolute GDP/GNP based upon the inclusion of all LDCs. All states are further classified according to whether they are land-locked, littoral, islands or archipelagic.

Table 1

Population, GDP and PPP Incomes in Small States and LDCs* State

Population 1998

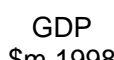

\$m 1998
GDP Per Capita \$ PPP 1998
Topography ${ }^{1}$

Group 1: Least Developed States

Sub-Saharan Africa

\begin{tabular}{lr} 
Comoros & 531 \\
Congo, Rep & 2,790 \\
Equatorial Guinea & 432 \\
Gambia & 1,216 \\
Guinea-Bissau & 1,161 \\
Lesotho & 2,060 \\
Liberia & 2,969 \\
Mauritania & 2,530 \\
Sao Tome and Principe & 142 \\
Angola & 12,090 \\
Benin & 6,040 \\
Burkina Faso & 10,680 \\
Burundi & 6,300 \\
Cameroun & 14,310 \\
Central African Rep & 3,490 \\
Chad & 7,270 \\
Eritrea & 14,290 \\
& $3,574^{3}$ \\
\hline & \\
\hline
\end{tabular}

\begin{tabular}{|c|c|}
\hline 196 & 1,480 \\
\hline 1,900 & 1,430 \\
\hline 647 & 4,400 \\
\hline 413 & 1,430 \\
\hline 186 & 750 \\
\hline 1,200 & 2,320 \\
\hline- & - \\
\hline 1,000 & 1,660 \\
\hline 40 & 1,350 \\
\hline 4,100 & 840 \\
\hline 2,300 & 1,250 \\
\hline 2,600 & 1,020 \\
\hline 900 & 620 \\
\hline 8,700 & 1,810 \\
\hline 1,000 & 1,290 \\
\hline 1,700 & - \\
\hline 0,100 & 1,730 \\
\hline 800 & 950 \\
\hline
\end{tabular}

2

0

0

0

0

0 


\begin{tabular}{|c|c|c|c|}
\hline Ethiopia & 59,880 & 6,100 & 500 \\
\hline Ghana & 19,160 & 7,200 & 1,610 \\
\hline Guinea & 7,340 & 3,800 & 1,760 \\
\hline Kenya & 29,010 & 9,700 & 1,130 \\
\hline Madagascar & 15,060 & 3,800 & 900 \\
\hline Malawi & 10,350 & 2,100 & 730 \\
\hline Mali & 10,690 & 2,600 & 720 \\
\hline Mozambique & 16,920 & 3,600 & 850 \\
\hline Niger & 10,080 & 1,900 & 830 \\
\hline Nigeria & 106,410 & 36,400 & 820 \\
\hline Rwanda & 6,600 & 1,900 & 690 \\
\hline Senegal & 9,280 & 4,800 & 1,710 \\
\hline Sierra Leone & 4,570 & 700 & 390 \\
\hline Somalia & $9,491^{2}$ & - & - \\
\hline Sudan & 28,347 & 8,221 & 1,360 \\
\hline Tanzania & 32,100 & 6,700 & 490 \\
\hline Togo & 4,400 & 1,500 & 1,390 \\
\hline Uganda & 21,030 & 6,700 & 1,170 \\
\hline Zaire (Congo DR) & 49,140 & 5,300 & 750 \\
\hline Zambia & 10,100 & 3,200 & 860 \\
\hline Zimbabwe & 12,680 & 7,100 & 2,150 \\
\hline
\end{tabular}

South Asia

\begin{tabular}{|c|c|c|c|}
\hline Bhutan & 1,600 & - & - \\
\hline Bangladesh & 124,770 & 44,000 & 1,100 \\
\hline India & 970,930 & 421,300 & 1,700 \\
\hline Nepal & 21,840 & 4,800 & 1,090 \\
\hline Pakistan & 131,510 & 63,200 & 1,560 \\
\hline Sri Lanka & 18,770 & 15,200 & - \\
\hline
\end{tabular}

Middle East and North Africa

Yemen

17,070

4,900

740

0

Eastern Europe and Central Asia

$\begin{array}{lr}\text { Afghanistan } & 23,481^{3} \\ \text { Albania } & 3,790\end{array}$

3,790

2,700

810 


$\begin{array}{lcccc}\text { Armenia } & 3,790 & 1,800 & - & 1 \\ \text { Azerbaijan } & 7,910 & 3,900 & 1,820 & 0 \\ \text { Bosnia-Herzegovina } & 4,383^{3} & - & - & 0 \\ \text { Georgia } & 5,400^{3} & 5,100 & - & 0 \\ \text { Kyrgyzstan } & 4,800 & 1,600 & 2,200 & 1 \\ \text { Moldova } & 3,650 & 1,800 & - & 0 \\ \text { Tajikistan } & 5,836^{3} & 2,100 & - & 1 \\ \text { Turkmenistan } & 4,508^{3} & - & - & 0 \\ \text { Ukraine } & 50,500 & 42,700 & - & \end{array}$

Latin America and Caribbean

$\begin{array}{lrrrr}\text { Guyana } & 857 & 660 & 2,680 & 0 \\ \text { Haiti } & 7,650 & 3,100 & 1,250 & 0 \\ \text { Honduras } & 6,180 & 4,500 & 2,140 & 0 \\ \text { Nicaragua } & 4,810 & 2,127 & 1,790 & 0\end{array}$

East Asia and Pacific

$\begin{array}{lr}\text { Mongolia } & 2,400 \\ \text { Solomon Islands } & 415 \\ \text { Cambodia } & 11,440 \\ \text { China } & 1,255,700 \\ \text { Laos } & 5,160 \\ \text { Myanmar } & 44,500 \\ \text { Vietnam } & 73,500^{3}\end{array}$

$\begin{array}{lll}1,000 & 1,520 & 1\end{array}$

$311 \quad 2,080$

$\begin{array}{lll}3,000 & 1,240 & 1\end{array}$

$\begin{array}{lll}928,900 & 3,220 & 0\end{array}$

$\begin{array}{lll}1,600 & 1,300 & 1\end{array}$

$\begin{array}{lll}253,780 & - & 0\end{array}$

$\begin{array}{lll}25,600 & 1,690 & 0\end{array}$

\section{Group 2: Less Developed States}

Sub-Saharan Africa

$\begin{array}{lr}\text { Cape Verde } & 4120 \\ \text { Djibouti } & 653 \\ \text { Namibia } & 1,660 \\ \text { Swaziland } & 988 \\ \text { Mayotte (F) } & 126\end{array}$

South Asia

Maldives

Middle East and North Africa

437

2,950

3,200

4,950

3,580 


$\begin{array}{lrrrr}\text { Madeira }(P)^{2} & 255 & - & 6,100 & 3 \\ \text { Algeria } & 29,800 & 46,500 & 4,380 & 0 \\ \text { Egypt } & 65,980 & 79,200 & 3,130 & 0 \\ \text { Iran } & 61,840 & 109,600 & - & 0 \\ \text { Iraq } & 21,800 & - & - & 0 \\ \text { Jordan } & 6,300 & 6,900 & 3,230 & 0 \\ \text { Morocco } & 27,780 & 34,800 & 3,120 & 0 \\ \text { Syria } & 15,600 & 15,600 & 3,000 & 0 \\ \text { Tunisia } & 9,330 & 19,200 & 5,160 & 0 \\ \text { Turkey } & 63,450 & 200,500 & & -\end{array}$

0

0

0

0

0

0

0

0

Eastern Europe and Central Asia

Estonia

Latvia

Macedonia, FYR

Belarus

1,450

2,450

$2,075^{3}$

10,190

Bulgaria

Kazakhstan

Lithuania

Romania

Russian Fed

Uzbekistan

Yugoslavia

Latin America and Caribbean

$\begin{array}{lr}\text { Belize } & 236 \\ \text { Dominica } & 74 \\ \text { Jamaica } & 2,540 \\ \text { Panama } & 2,760 \\ \text { St Vincent and Grenadines } & 113 \\ \text { Suriname } & 413 \\ \text { Bolivia } & 7,950 \\ \text { Colombia } & 40,830 \\ \text { Costa Rica } & 3,530 \\ \text { Cuba } & 11,011^{3}\end{array}$

$\begin{array}{rrr}4,900 & - & 0 \\ 5,900 & - & 0 \\ 2,660 & 3,660 & 1 \\ 22,510 & - & 1 \\ 10,100 & - & 0 \\ 20,600 & 3,400 & 0 \\ 9,000 & 4,310 & 0 \\ 31,300 & 3,970 & 0 \\ 337,900 & 3,950 & 0 \\ 20,900 & 2,900 & 1 \\ - & - & 0\end{array}$

$\begin{array}{lll}615 & 3,940 & 0\end{array}$

$222 \quad 3,940 \quad 2$

$\begin{array}{lll}4,300 & 3,210 & 2\end{array}$

$\begin{array}{lll}8,500 & 6,940 & 0\end{array}$

$274 \quad 4,090$

$685-0$

$\begin{array}{lll}7,900 & 2,820 & 1\end{array}$

$\begin{array}{lll}106,100 & 7,500 & 0\end{array}$

$\begin{array}{lll}9,800 & 6,620 & 0\end{array}$ 


$\begin{array}{lrrrr}\text { Dominican Rep } & 8,100 & 14,600 & 4,770 & 0 \\ \text { Ecuador } & 12,170 & 18,600 & 4,630 & 0 \\ \text { El Salvador } & 6,030 & 11,200 & 2,850 & 0 \\ \text { Guatemala } & 10,800 & 17,700 & 4,070 & 0 \\ \text { Paraguay } & 5,220 & 9,200 & 3,650 & 1 \\ \text { Peru } & 24,800 & 61,100 & - & 0\end{array}$

East Asia and Pacific

203

3

$\begin{array}{ll}\text { Fiji } & 827\end{array}$

1,745

3,580

3

Kiribati

101

3,480

3

Marshall Islands

Samoa

176

180

3,440

2

Tonga

167

3,860

3

Vanuatu

231

3.160

2

Indonesia

204,402

138,500

2,790

3

Korea DR

23,171

Papua New Guinea

4,600

4,100

2,700

Philippines

75,150

78,900

3,540

Thailand

61,200

134,400

5,840

Sub-Saharan Africa

$\begin{array}{lr}\text { Botswana } & 1,570 \\ \text { Gabon } & 1,181 \\ \text { Mauritius } & 1,159 \\ \text { Seychelles } & 79\end{array}$

5,600

8,310

4,664

6,660

4,288

9,400

10,530

St Helena and Deps (UK)

Middle East and North Africa

$\begin{array}{lr}\text { Bahrain } & 641 \\ \text { Oman } & 2,322 \\ \text { Canary Islands }(E)^{2} & 1,526 \\ {\text { Ceuta and Melilla }(E)^{2}}^{2} & 126\end{array}$

6,184

10,460

Eastern Europe and Central Asia 
Latin America and Caribbean

Antigua and Barbuda

Barbados

Grenada

St Kitts and Nevis

St Lucia

Trinidad and Tobago

Anguilla (UK)

Guadeloupe (F)

East Asia and Pacific

American Samoa (USA)

Western Europe

Malta

Isle of Man (UK)

Group 4: High Income States

Sub-Saharan Africa

Reunion (F)

Middle East and North Africa

Kuwait

2,030

Qatar

United Arab Emirates

2,671

Latin America and Caribbean
Aruba (NL)

Cayman Islands (UK)

Falkland Islands (UK)

Guiane (F)

Martinique $(F)$

Netherlands Antilles (NL)

US Virgin Islands (USA)

East Asia and Pacific 


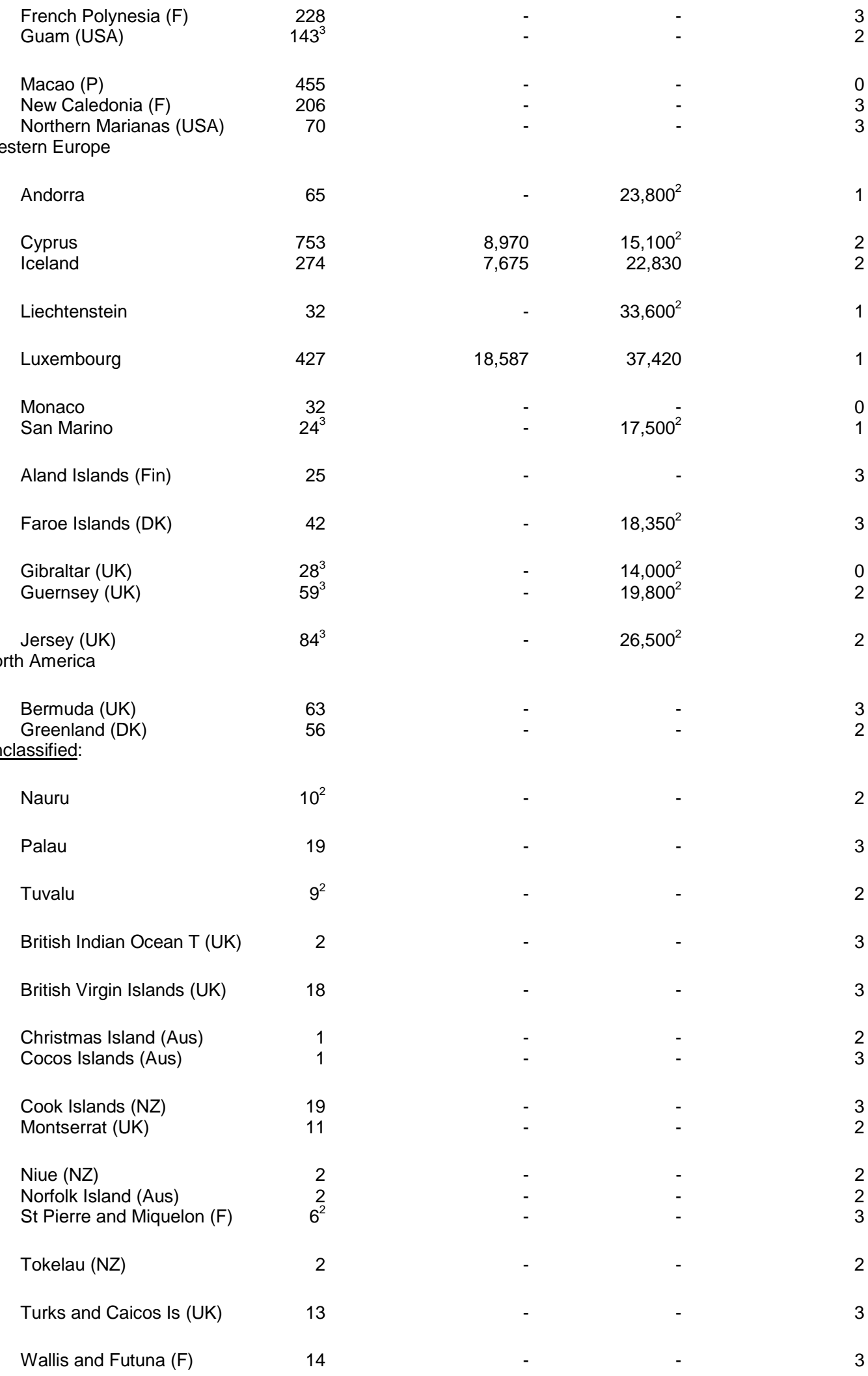

3

2

0 3

1

0 


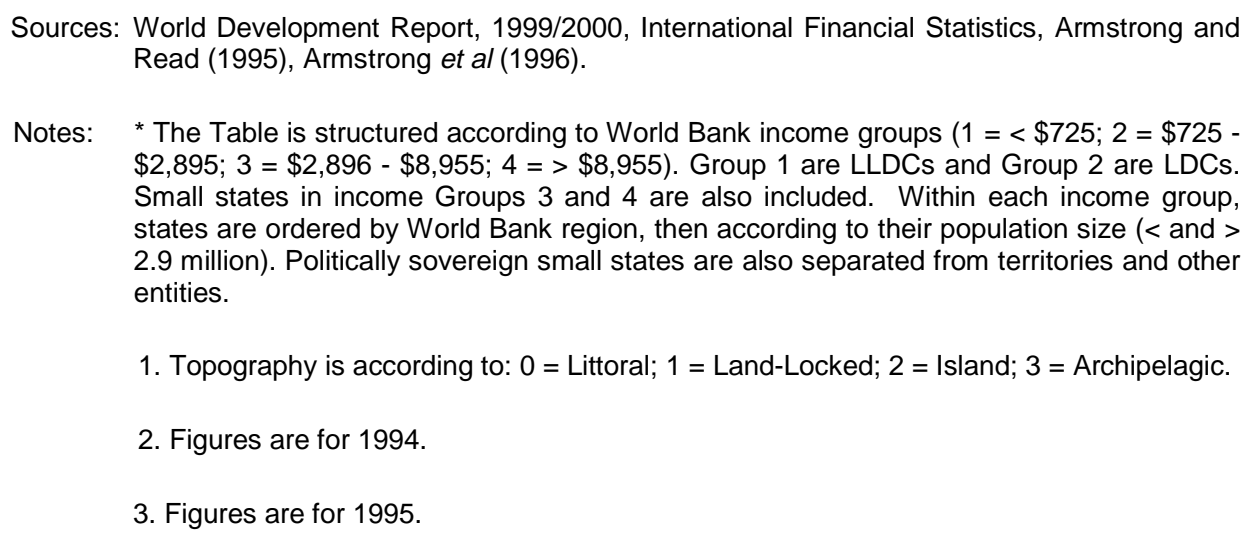

\section{Sub-optimality and size constraints on growth in small states}

Interest in the economic performance of small states is a result of the rapid increase in the number of independent small states in the international economy in recent decades. There has also been a concurrent trend towards the decentralisation of political and economic policy-making in many larger states, especially in Western Europe, leading to a growth in the number of autonomous regional entities. Nevertheless, inferences derived from economic theory suggest that small states encounter significant additional challenges in their growth processes because of their small size. The basis for this argument is that the economic structure of small states is adversely affected by their difficulty in achieving sufficient economies of scale in a wide range of basic economic activities. Small size is therefore viewed as impeding the growth process because it renders small states sub-optimal in economic terms. This is essentially the same argument that is applied to the problems of low absolute GDP/GNP in LDCs, discussed in Section 1.

\subsection{The economic sub-optimality of small states}

It is useful at this point to consider why small size might be expected to have an adverse impact on the economic performance of small states. In spite of the extensive literature on small states, few studies actually address the fundamental issue of economic smallness and the extent to which critical economic assumptions cease to hold.

The 1957 IEA Conference on the consequences of the size of nations (Robinson, 1960) provides many original insights which have been developed further to create a more robust and consistent analytical economic framework (notably, Jalan, 1982a; Ashoff, 1989; Srinivasan, 1986; Streeten, 1993; Armstrong and Read, 1995, 2000; Armstrong et $a l, 1996,1998)$. The focus is the implications for the economic analysis of small states when dispensing with certain standard but inapplicable neo-classical economic assumptions; constant returns to scale, perfect competition and zero transport costs. The imperfect markets approach therefore conceptualises the economies of small states as being sub-optimal (Armstrong and Read, 1995). This perspective highlights the crucial 
impact of scale economies, indivisibilities, efficiency and competitiveness (Scitovsky, 1960) as well as diseconomies of scope (Streeten, 1996) on the potential of small economies to generate a 'critical mass' in domestic economic activity.

The focus on economic sub-optimality provides a useful, rigorous and more generally applicable theoretical framework for the analysis of small states. This facilitates improved understanding of their salient economic characteristics and implications so as to provide more effective policy prescription. In addition, the approach fits well with the use of population and/or GDP/GNP as an indicator of small size. Although suboptimality is not a perfectly robust concept, it is both theoretically elegant and potentially fertile as the principal unit of analysis. The incorporation of production and trade, and their interaction, is activity-specific and homogenous between states to the extent that tastes and technology are similar. Small states can therefore be considered independently of their topography in terms of the inability to generate the critical mass of domestic economic activities, including those usually regarded as non-tradeables, which can be reasonably expected within a state.

\subsection{The salient economic characteristics of small states}

The literature exhibits a substantial degree of consensus concerning the general economic characteristics of small states in spite of the diversity of views as to what constitutes small size. This discussion is concerned with outlining the key characteristics of small states and their implications for economic performance in the context of the sub-optimality approach outlined above.

\subsubsection{The small size of the domestic market}

The small size of the domestic market in small states follows directly from the critical mass of domestic activity being sub-optimal. Insufficient domestic demand to reach the minimum efficient scale (MES) necessary for the efficient output for many goods and services raises unit costs of local production. The range and extent of economic activity in a small state is therefore a function of the shape of average cost curves below the MES (Knox, 1967) and the cost of transportation. Small states are thus at a structural disadvantage relative to larger states with respect to nurturing large scale industries, particularly those associated with high growth effects (Thomas, 1982). This argument can also be applied to Rand, technical progress and technology acquisition in small states since their small size inhibits the development of indigenous technologies (Selwyn, 1975; Briguglio, 1995).

A small domestic market also inhibits competition in many of the domestic economic activities which do take place because of the small number of feasible incumbent firms-equal to the market size over the MES (Kuznets, 1960). This problem is most acute where there are indivisibilities in production, particularly if they affect vertical production stages. A small domestic market therefore creates a natural barrier to entry which may also affect domestic service activities, including distribution and retailing (Armstrong et al, 1993). This increases the likelihood that a small domestic market will be characterised by monopoly or oligopoly with adverse implications for welfare. The lack of competition raises the prices of goods and services further with knock-on effects on the cost of inputs into other activities, notably utilities and other infrastructural 
services. The impact of a small domestic market is likely to be particularly severe on non-tradeables because of the potential cost of alternative imports. It will however, also affect those tradeables which are subject to diseconomies of scale and lack of competition in transportation and distribution as well as those prone to stock-outs.

The cost of living in small states can therefore be expected to be higher than in larger states, for reasons of scale and competition, together with a narrower range of consumer choice. These effects may be exacerbated in more geographically isolated small states, whether islands or land-locked, because the extent to which many goods and services can actually be traded is determined by the cost of transportation. The magnitude of these adverse effects may be assuaged by low scale economies and potential economies of scope in some activities (Streeten, 1996) such that the marginal cost of additional output is low, particularly where productive assets have alternative uses.

\subsubsection{The limited domestic resource base}

The natural resource endowment of a small state is partly a function of geographic area and/or EEZ as well as the result of serendipity. Although small size does not preclude an abundance of natural resources, states with small geographic areas are likely to have limited and relatively undiversified endowments. Even where natural resources are present, many small states may lack sufficient domestic sources of capital to finance their exploitation.

A small population also imposes a severe constraint on the domestic supply of labour. This limits the relevance of standard models of structural transition in developing economies founded upon the assumption of unlimited supplies of labour. The domestic agricultural sector acts as a strategic hinterland supplying food, labour and savings to urban areas and absorbing domestic output of manufactures. In small developing states, the agricultural sector is likely to be too small to do this effectively and this may be a distinct advantage. A traditional agricultural sector is generally regarded as hindrance to growth because it is characterised by subsistence output, low productivity, technological backwardness and low incomes while surplus labour depresses wages across the economy.

Although a severe scarcity of labour might be regarded as an advantage, it imposes a critical constraint on the appropriateness of labour-intensive industrialisation. Small developing states are unlikely to be able to compete with larger industrialising countries in low-skilled labour-intensive export sectors. Growth is therefore more likely to be the outcome of higher value-added activities which are intensive in their use of human capital, skills and physical capital (Bhaduri et al, 1982). Investment in human capital is therefore critically important to their long-term economic health. The provision of education and training is also subject to increasing returns to scale and is increasingly costly at higher levels of specialisation. It is nevertheless essential that small states possess a full range of essential specialist professional, technical and administrative skills almost irrespective of cost. The thinness of the local market in some specialised skills means that small states are highly susceptible to the effects of the brain drain. 


\subsubsection{The narrow structure of domestic output, exports and export markets}

The interaction between the small size of the domestic market, the MES and the labour supply constraint means that small states are necessarily highly specialised and comparatively undiversified in the structure of their output and exports. This may give rise to an excessive dependence upon a few dominant activities, exports and export markets. This dependence may be aggravated by the shallowness of local inter-industry linkages given the narrow domestic economic base (Selwyn, 1975). Export concentration increases the exposure to exogenous shocks in the form of unstable export prices and earnings, and possibly 'Dutch' disease (Corden and Neary, 1982).

The effect of instability on small states is greater because they are generally international price takers and their domestic supply is constrained. They have little influence over fluctuations in their export (and import) prices and are unable to compensate for declining export prices through increased export volumes. Diversification is the general solution to problems of export concentration and instability although this is highly constrained in small states by the size of the domestic economy. Further, small states lack both the market power and the domestic resource base to fully ameliorate the impact of any external shocks. Specialisation may also impede potential diversification by reducing the availability and mobility of certain scarce skills.

\subsubsection{The structural openness to trade}

The small size of the domestic market in small states coupled with a high degree of output specialisation greatly restricts the range of goods and services which they can feasibly source locally. This gives rise to significant asymmetries between the patterns of domestic production and consumption, resulting in high levels of import dependency (Kuznets, 1960). The small domestic market is therefore unlikely to drive autonomous self-sustaining internal growth, limiting the potential for growth strategies based upon import-substituting industrialisation. Small states must therefore necessarily pursue highly open trade regimes and be well-integrated with the international economy, with important implications for policy (Kuznets, 1960; Marcy, 1960; Scitovsky, 1960; Triffin, 1960).

The high level of structural openness of small states and the importance of trade to their GDP/GNP means that integration with the global trading system creates a critical risk asymmetry. Price fluctuations in exports due to exogenous shocks are likely to be greater than for imports. This has serious domestic implications in terms of the risk of Balance of Payment problems, foreign exchange constraints on essential imports and an unstable growth path (Erbo and Schiavo-Campo, 1969; Lloyd and Sundrum, 1982; Thirlwall, 1991).

The extreme openness of the economies of small states also means that there is a high degree of international monetisation because of the large share of foreign currency transactions. This creates exposure to thin currency markets and exchange rate and foreign reserve instability which severely constrain domestic monetary autonomy (Ally, 1975; Helleiner, 1982). Many small states have therefore either linked their exchange rate to a hard currency or joined a hard currency area via pseudo-monetary integration (Read, 1995; Armstrong and Read, 1998, 1999; Chadha, 1999). This strategy provides insulation against external volatility at a cost of the loss of monetary sovereignty, 
including the determination of interest rates and inflation, in the absence of capital controls (Khatkhate and Short, 1980).

\subsubsection{Additional issues for land-locked and island micro-states}

The openness of small states means that maintaining low-cost trade links with the international economy is of paramount importance. This is of particular concern to landlocked and island/archipelagic small states which are more likely to suffer from remoteness and isolation and therefore higher transport costs. For land-locked states, there is a high degree of reliance/dependence on neighbouring states for surface communications and port facilities and therefore for access to export markets and import sources. Many small archipelagic states are highly fragmented such that internal communication may be as difficult and as costly as external links (Brookfield, 1975, 1990; Selwyn, 1978). Further, the impact of diseconomies of scale may be compounded by fragmentation with respect to the provision of essential economic and social infrastructure to outlying islands.

The effect of remoteness and isolation on transport costs, for both land-locked and island small states, is similar to a domestic tariff in terms of its impact on domestic production, consumption and welfare. The economic sub-optimality of small states implies that nearly all goods and services are tradeable at the margin. For remote and isolated small states however, it may be less costly to produce certain tradeables and non-tradeables domestically rather than rely upon imports given high transport costs. Nevertheless, the supply of some goods and services may be infeasible.

\section{i2.3 The implications of size for the growth of small states}

The salient characteristics identified in Section 2.2 have critical implications for small states to the extent that they constitute a significant constraint on the structure of economic activity and restrict economic policy autonomy. The general view of the literature is that any potential advantages for small states conferred by their small size are greatly outweighed by their inherent disadvantages. This suggests that small states are likely to experience significant challenges in generating and sustaining economic growth relative to larger states.

The principal potentially advantageous economic characteristic is size-induced openness to trade (Ashoff, 1989). The high degree of trade intensity necessary because of their critical dependence on both imports and exports requires small states to ensure that they are internationally competitive. Small states are therefore more likely to favour policies promoting export-led growth than are larger countries (Armstrong et al, 1996, 1998). Further, the potential gains from trade are also significant because of the magnitude of the trade multiplier in small states (Ashoff, 1989). International trade however, cannot completely offset the adverse effects of small size because of the increased exposure to exogenous shocks.

An additional non-economic characteristic that is argued to be a potential source of advantage for small states is social cohesion. This refers to the networks of trust and norms of reciprocity which stimulate the formation of social capital through greater communal interaction leading to greater consensus in economic management and 
policy-making (Putnam et al, 1993). Because of their small size, small states are potentially more responsive to change and more flexible in their policy-making, so providing a fertile environment for economic growth. Paradoxically, the short distance and frequency of direct contact between decision-makers and constituents in small states may also encourage divisive rent-seeking behaviour based upon family ties or clientelism (Armstrong and Read, 2000).

Several early studies assert that the economic disadvantages facing small states are so great that they are not viable as independent economic entities and should therefore be absorbed by larger states or into federation (Labour Party, 1957; Blood, 1958; Benedict, 1967). Decolonisation by Britain favoured the larger colonies and was strongly influenced by the view that small size was inimical to development because of the critical role of scale economies in industrialisation. This view has not been borne out by the continued survival and prosperity of an increasing number of small states in the world economy. No small states have voluntarily chosen absorption or confederation, rather the opposite; the disintegration of the West Indian Federation and the departure of Singapore from the Malay Federation. Economic viability has therefore played only a secondary role to the issues of identity, independence and self-determination (Abbott, 1975).

\section{Explaining the growth of small states}

The general inference from theory is that small states experience significant obstacles to their long-run economic growth performance because of their size. If this is the case, small states can be expected to enjoy lower long-run rates of economic growth and lower per capita incomes than larger states. The critical issue is therefore the extent to which small size adversely affects long-term economic growth. This Section reviews the empirical evidence on the impact of size on growth as well as further explanations for the relative growth success of small states, including openness, the interaction between sectoral specialisation and comparative advantage, non-economic factors and dynamic policy issues.

\subsection{The impact of size on the growth of small states}

The apparent paradox between the increasing number of small states enjoying greater levels of economic and political sovereignty and their apparent economic sub-optimality is further complicated by the actual growth performance of small states. Cursory observation suggests that many small states, both developed and developing, have achieved sustained economic growth and relatively high levels of per capita incomes in spite of their small size. This is reflected in disproportionately fewer small states, using a simple population size measure of 3 million, being found in the World Bank's lowest income categories (Armstrong et al, 1998). In spite of their inherent economic suboptimality, small (population) size does not therefore appear to be an insurmountable constraint on the growth of small states. It is clear however, that sub-economic optimality greatly inhibits the scope for output specialisation and domestic policy autonomy in small states generally. 
The empirical evidence on the impact of small size on growth performance is inconclusive in spite of the strength of the a priori theoretical inferences. Empirical analyses of structural transformation find that, after normalising for the level of development, the role of country size is insignificant (Chenery and Taylor, 1968; Erbo and Schiavo-Campo, 1969; Kuznets, 1971; Chenery and Syrquin, 1975; Chenery et al, 1986). Further, specific testing of the effects of size on economic growth have failed to find any systematic adverse impact (Khalaf, 1971; Blazic-Metner and Hughes, 1982; Milner and Westaway, 1993; Armstrong et al, 1996, 1998). Moreover, there is some evidence to suggest that small states and autonomous regions in Western Europe have actually out-performed comparable regions in the European Union (Armstrong and Read, 1995).

The failure of these empirical results to confirm the intuition of theory concerning suboptimality does not preclude the adverse effect of small size on growth but rather that any such effects are insufficiently systematic to be significant. Several explanations can be proposed for this lack of empirical support. Most of these analyses suffer from significant methodological shortcomings in terms of definitional problems concerning small size and small data samples compounded by the lack of comprehensive harmonised data sets. Nevertheless, those studies using stratified sample data and more extensive, although non-harmonised, data sets still find no systematic negative relationship (Milner and Westaway, 1993; Armstrong et al, 1996, 1998). A broader methodological concern however, is that many small states have in fact been relatively successful in securing sustained economic growth and increasing per capita incomes while many larger comparator states, notably other LDCs/LLDCs, have performed relatively poorly. This suggests that additional economic factors play a critical role in relative growth performance, in particular the design and effectiveness of policies to foster economic growth.

\subsection{Openness and comparative advantage in small states}

International trade is critically important to small states because of their need to finance essential imports. Further, trade can alleviate many of the constraints associated with a sub-optimal domestic market size since increased specialisation improves domestic efficiency and competitiveness. Openness to trade is therefore not only necessary for small states because of the severity of the impact of autarky but also because it significantly increases the extent of their market. The magnitude of the trade multiplier means that these growth effects are particularly large because of structural opennessthe high proportion of trade in GDP/GNP. Any gains from increased specialisation through trade however, must be offset against the greater risks associated with concentration and the reduced degree of diversification of the domestic economy.

Because small states are generally price-takers in imports and exports, international trade has a contestable impact upon their domestic prices, efficiency and competitiveness. External pressures on costs and prices and the need to assure market access means that any domestic output of tradeable goods and services must be internationally competitive. The dominance of imports in consumption also means that both the tradeables and non-tradeables sectors pay world prices (plus transport costs) for most intermediate inputs. Contestability, subject to transport costs, therefore affects the 
entire tradeables sector and possibly some non-tradeables independent of the competitive structure of the domestic market (Armstrong and Read, 1998a).

The structural necessity for small states to pursue highly open trade policies requires their exports sectors to be internationally competitive and therefore founded upon sources of inherent comparative advantage. These lie in economic activities which are neither subject to increasing returns to scale nor reliant upon the intensive use of lowcost labour. This suggests that most successful small states can be expected to specialise in producing goods and services which embody human, and possibly financial, capital. This conclusion highlights the critical role of human capital accumulation as a source of dynamic comparative advantage and structural transition in small states.

\subsection{Structural transition, sectoral specialisation and growth in small states}

The sustained economic growth of many small states in spite of their inherent economic sub-optimality has led to increased theoretical and empirical interest in the critical determinants of this growth performance. There is increasing evidence to suggest that this growth success is associated with particular patterns of sectoral specialisation and the effective use of endogenous policies within an overall growth strategy.

Structural transition in developing economies is normally associated with Lewis-type industrialisation in larger countries with low productivity surplus agricultural labour shifting to more productive labour- (and technology-) intensive manufacturing (see Chenery and Syrquin, 1975; Chenery et al, 1986). This path of development is not open to most small states however, because of their relative lack of labour and the infeasibility of growth based upon large-scale expansion of a low-cost labour-intensive industrial sector (Lewis, 1954). The sources of growth in small states, and small developing states in particular, do not therefore conform to the orthodox model of industrialisation (Demas, 1965). Instead, they can be expected to specialise in activities, such as natural resources and higher value-added niche manufacturing and service activities, which utilise human capital intensively and are less reliant upon scale economies (Bhaduri et al, 1982).

The UNCTAD structural typology of small island developing states (SIDS) classifies them according to their principal economic activities (UNCTAD, 1997). An extended and modified version for all small states with populations below 3 million (see Armstrong and Read, 1998) is shown in Table 2. The UNCTAD typology identifies four principal structural types of small state. Type I states are dependent upon significant external rental income, primarily in the form of overseas remittances by migrant workers (MIRAB economies). Type Ia lack an indigenous productive base while Type Ib have some limited productive activities. Type II states are dependent upon significant natural resource exports, including agricultural products. Type IIa are relatively undiversified and possibly lacking in supporting service activities while Type IIb are more diversified with better developed inter-sectoral linkages and some possible niche activities. Type III states are dependent upon significant earnings from services, primarily tourism and business services, including offshore finance without (Type IIIa) and with (Type IIIb) other productive activities. Type IV have diversified economies, generally including a relatively large manufacturing sector. This category is, to some extent, self-contradictory since states in this group tend to have larger 
populations than those in the other three groups. Comparing average levels of per capita income and growth rates for each group in this typology, specialisation in services is argued to have a strong positive impact upon economic performance (UNCTAD, 1997). It is difficult to derive robust policy conclusions concerning appropriate strategies for fostering growth in small states however, given that UNCTAD do not investigate any causal relationship between sectoral specialisation and growth performance.

Table 2

Classification of small economies: UNCTAD typology

\begin{tabular}{|c|c|}
\hline Type la: & $\begin{array}{l}\text { Falkland Islands; Marshall Islands; Federated States of } \\
\text { Micronesia; Niue; Northern Mariana Islands; Sao Tome and } \\
\text { Principe; Tokelau; Tuvalu; Wallis and Futuna }\end{array}$ \\
\hline Type lb: & $\begin{array}{l}\text { Cape Verde; Cook Islands; French Polynesia; Guam; New } \\
\text { Caledonia; Samoa; Tonga }\end{array}$ \\
\hline Type Ila: & $\begin{array}{l}\text { American Samoa; Brunei; Congo (Republic); Equatorial } \\
\text { Guinea; Faroe Islands; Gabon; Greenland; Guadeloupe; } \\
\text { Guinea-Bissau; Kuwait; Liberia; Mauritania; Mayotte; Nauru; } \\
\text { Oman; Palau; Qatar; Reunion; St Helena; St Pierre and } \\
\text { Miquelon; Solomon Islands; UAE }\end{array}$ \\
\hline Type Ilb: & $\begin{array}{l}\text { Aruba; Belize; Bhutan; Botswana; Comoros; French Guiana; } \\
\text { Gambia; Guyana; Iceland; Jamaica; Martinique; Mongolia; } \\
\text { Namibia; Panama; Suriname; Swaziland }\end{array}$ \\
\hline Type Illa: & $\begin{array}{l}\text { Andorra; Anguilla; Antigua and Barbuda; British Virgin Islands; } \\
\text { Cayman Islands; Djibouti; Guam; Kiribati; Montserrat; Turks } \\
\text { and Caicos Islands; US Virgin Islands }\end{array}$ \\
\hline Type IIlb: & $\begin{array}{l}\text { Azores; Bahamas; Barbados; Bermuda; Canary Islands; } \\
\text { Dominica; Gibraltar; Grenada; Guernsey; Isle of Man; Jersey; } \\
\text { Liechtenstein; Luxembourg; Macao; Madeira; Maldives; } \\
\text { Netherlands Antilles; St Kitts and Nevis; St Lucia; St Vincent } \\
\text { and Grenadines; San Marino; Seychelles; Vanuatu }\end{array}$ \\
\hline Type IV: & $\begin{array}{l}\text { Bahrain; Cyprus; Estonia; Fiji; Latvia; Lesotho; Macedonia; } \\
\text { Malta; Mauritius; Singapore; Slovenia; Trinidad and Tobago }\end{array}$ \\
\hline \multicolumn{2}{|c|}{ Source: Armstrong and Read (1998), } \\
\hline \multirow[t]{3}{*}{ Note: } & Type I, external rental income, including aid > export and service income. \\
\hline & Type II, export income > service income. \\
\hline & Type III, service income > export income. \\
\hline
\end{tabular}

The relationship between sectoral specialisation and growth in small states is also investigated using conventional growth models and other statistical techniques applied to an extensive global data set of small states (Armstrong and Read, 1995, 2000; Armstrong et al, 1996, 1998). Sectoral analysis finds that growth success, measured in terms of per capita income, is associated with a rich natural resource base and a strong service sector, notably in financial services and tourism. The presence of a significant agricultural sector however, is associated with a relatively poor growth performance. These empirical findings support a priori reasoning concerning the inherent comparative advantages of small states. The positive impact of natural resources on growth runs 
counter to the argument of the 'resource curse' thesis (Auty, 1993), possibly because their greater social cohesion makes small states more effective in sharing any such gains. The findings also suggest that advances in communication technology are of increasing benefit to remote small states, such as The Maldives and Mauritius, in their provision of offshore services and long-haul tourism.

\subsection{Alternative determinants of growth in small states: the role of islandness, region and sovereignty}

The theoretical discussion of small states in Sections 1 and 2 highlights the critical potential role of additional non-economic factors in influencing the growth success of small states. Although some of these factors are difficult to quantify easily, such as social cohesion, others can be quantified relatively simply, notably islandness, broader geographical region and political sovereignty. Nevertheless, empirical analysis of the contribution of these factors to the growth of small states is very limited.

\subsubsection{Islandness and growth in small states}

Islandness is regarded as a critical determinant of growth in small states because of the impact of remoteness/isolation coupled with transport costs. Nevertheless, there has only been very limited empirical analysis of its impact on growth. The role of islandness has however, been investigated using cross-section discriminant analysis for Western European data (Armstrong and Read, 1995) and for an extensive global data set using the same technique together with censored regression (Armstrong et al, 1996, 1998; Armstrong and Read, 2000). Islandness, represented by a simple binary variable in the discriminant analyses, is expected a priori to be negatively related to GNP per capita in small states. Contrary to expectations however, islandness is found to have both negative and positive coefficients but with a generally weak effect on income levels. The use of more powerful censored regression produces the expected negative sign for islandness but with very low levels of significance (mostly below 85\%). This result indicates that islandness does appear to be negatively related to the economic performance of small states but suggests that its impact is considerably weaker than is implied in much of the theoretical literature.

\subsubsection{Regional or locational determinants of growth}

In general, very little attention has been paid to the impact of location on the growth of small states except in terms of their remoteness/isolation from world markets. An alternative perspective is to investigate the role of the broader region in which small states are located since they are at least partly dependent upon the economic well-being of markets in adjacent states. Location in a relatively wealthy region is likely to be advantageous in that it offers small states easier access to larger and more buoyant export markets.

Using World Bank definitions of global regions within a discriminant analysis for an extensive global data set, the region variable is found to be a significant factor in determining the GNP per capita in small states (Armstrong et al, 1996, 1998; Armstrong and Read, 2000, 2001). This result is further confirmed by the significance of the region variable in the censored regression analysis. These empirical findings suggest that 
regional markets and regional forces remain very powerful influences in growth in spite of globalisation.

\subsubsection{The impact of political sovereignty on growth}

The discussion of economic and political sovereignty in Section I is concerned with the extent to which autonomous economic policy-making is possible. It is evident from Section 2 however, that small states possess very limited scope for economic policy autonomy because of their size and consequent structural openness to trade. The critical issue for small states is therefore the effectiveness with which their limited policy autonomy is utilised, (see Section 3.5).

Relatively little attention has been paid in the literature to the issue of policy sovereignty in small states, primarily because empirical analysis of economic sovereignty is hampered by severe data limitations. Political sovereignty according to the UN definition however, can be used as a simple binary variable to distinguish between small sovereign states and other small territorial entities. Empirical analysis of the effect of political sovereignty on GNP per capita finds that it has a consistently negative sign with $95 \%$ significance, further confirmed by censored regression analysis (Armstrong and Read, 2000). This finding suggests that small dependent states possess additional advantages independently of other determinants of economic performance. Fiscal transfers from metropolitan powers are usually regarded as a key advantage for dependent territories. Incorporating aid transfer data however, does not significantly alter the overall findings concerning political sovereignty (Armstrong and Read, 2000).

The findings on the relationship between political sovereignty and growth in small states are unexpected and certainly contrary to expectation. The results need to be interpreted with care since political sovereignty is not synonymous with economic sovereignty and should not therefore be regarded necessarily as an appropriate proxy. Further, the extent of economic, as well as political, sovereignty is severely constrained by small size. Economic growth however, is very likely to be dependent upon the effectiveness with which any endogenous as well as exogenously-determined policies are utilised; ie, the quality of domestic policy-making and growth strategies.

\subsection{Endogenous growth strategies in small states}

The relative growth success of many small states requires further investigation of their growth strategies, particularly with respect to the implementation of endogenous policies which at least partly offset some of the adverse effects of economic suboptimality (following Marcy, 1960; Scitovsky, 1960; Svennilson, 1960; Triffin, 1960). In spite of economic policy constraints, there still remains considerable scope for them to pursue strategic policy objectives (see Kakazu, 1994; Armstrong and Read, 1998, 1999). The potential impact of optimal policy formulation on the growth performance of (very) small open economies can be discussed in the context of two distinct but complementary perspectives, endogenous growth theory and international political economy. 


\subsubsection{Small states and endogenous growth theory}

Endogenous growth theory is concerned with the analysis of the impact of endogenously-determined policy variables on relative rates of economic growth between countries. The additional structural and 'conditioning' variables incorporated into formal growth models, such as the Neo-Classical conditional convergence growth model (Barro, 1991; Barro and Sala-i-Martin, 1991, 1992), are in this case determined endogenously. The theoretical literature highlights several important conditioning variables (see Edwards, 1993; Temple 1999), two of which are highly relevant in the context of the economic performance of small states. Openness to trade is argued to have beneficial effects on domestic competitiveness through imports embodying high levels of technology. The propensity to absorb advanced technology however, will depend upon the endowment of human capital, also identified as a key variable in the growth literature. Investment in human capital formation, through education, training and learning-by-doing, has long-term beneficial effects on productivity and growth because it is not subject to diminishing returns.

The importance of openness and human capital in endogenous growth theory has important ramifications for the growth of small states. The high degree of structural openness to trade in small states because of their size has already been identified as a critical growth factor because of its domestic multiplier effects. Although all small states are structurally open to trade however, they still possess some scope for endogenous trade policy - functional openness. Structural openness therefore offers considerable potential growth benefits (Ashoff, 1989) but some small states may choose a more protectionist trade policy stance. Human capital is as a key source of comparative advantage in small states, because of labour supply constraints, such that investment in human capital formation can be expected to be strongly associated with growth success (Pissarides, 1996). Such investment will also enhance the absorptive capacity for technology embodied in imports. This is particularly important for small states because of the prevalence of increasing returns to scale in $\mathrm{R} \& \mathrm{D}$ and innovation (Briguglio, 1995).

The insights of endogenous growth theory suggest that small states are well-placed to enjoy relatively high rates of growth, in spite of their economic sub-optimality, because of their high degree of openness to trade and propensity for human capital formation. Measurement difficulties and problems of data availability mean that these inferences lack empirical verification.

\subsubsection{International political economy issues}

International political economy is concerned with the strategic behaviour of countries, driven by rational self-interest but often giving rise to non-pareto (second-best) global welfare effects. This provides a useful context for analysing the interaction between endogenous policy choice and the potential growth performance of small states. Their size provides small states with opportunities to exploit their relative unimportance in the global economy through international free-riding, international rent-seeking and strategic location (discussed at length in Armstrong and Read, 1999).

The ability of small states to free-ride internationally may generate considerable benefits without cost and arises directly from their small size and relative global unimportance. This is probably most evident with respect to defence given that most 
small states encounter significant diseconomies in its provision (Kuznets, 1960). Many small states therefore eschew onerous domestic defence expenditure and instead enjoy significant positive externalities from relying upon the UN to uphold their territorial integrity. Small states are also likely to be the biggest beneficiaries of a relatively liberal international trade regime. The reciprocal multilateralism of the GATT and WTO agreements are specifically designed to generate positive externalities for weaker member countries through trade liberalisation. Many small states have adopted hard currencies as a means to avoid the exchange rate and macroeconomic volatility associated with a high degree of openness and import dependence. Several pseudocurrency areas have emerged where monetary autonomy is retained by the national central bank and small member states are able to free-ride on the credibility of the hard currency. This appears to have been particularly important for those small states which have established successful offshore financial centres.

International rent-seeking by small states takes a number of forms. Perhaps of greatest interest is the creation of a powerful pressure group within the UN organisations. Decisions are based upon the principle of one country-one vote regardless of size while members' budgetary contributions are generally both size- and means-related subject to a minimum threshold. Sovereign small states are therefore able to exploit their bloc vote to 'punch above their weight' in shaping the international regulatory framework. The sustained growth of small states is critically dependent upon their assured access to a limited number of key export markets, highlighting their need to devise policy strategies to maintain these links. Many small states have been surprisingly successful in securing non-reciprocal asymmetric bilateral trade concessions with larger countries and regional trade blocs, notably with the EU (Armstrong and Read, 1995). This granting of such preferences is of negligible cost to the donor country/bloc but generate significant rents for the beneficiary. The participation of small states in formal regional integration schemes however, is less prevalent than might be expected. Although small states are argued to be the greatest likely gainers from economic integration (Graham, 1923; Balassa, 1962), this is predicated upon significant pre-integration protection. The openness of most small states however, suggests that economic integration involves a critical loss of trade policy autonomy such that the extent of the market might actually be reduced (Rothschild, 1944; 1963; Armstrong and Read, 1998b). Many successful small states have used their policy autonomy to establish appropriate regulatory frameworks and set strategic taxation rates so as to attract niche offshore financial activities. Rent-seeking in this case takes the form of tax competition with onshore centres (Keen, 1996). Rent-seeking by small states also occurs with respect to labour migration. There has been significant out-migration of labour from some poorlydeveloped small states, particularly in the Pacific, facilitated by former colonial links and free labour mobility with some larger states. This has resulted in many of these states becoming highly dependent upon inflows of worker remittances-Type I economies in the UNCTAD typology. Policy autonomy over immigration has been used by wealthier small states to overcome their labour supply constraints and alleviate specific skill-deficits by granting temporary residency while restricting the right to permanent residence.

The strategic geographic location of many small states, particularly islands, their remoteness and their distinctive identity are also sources of potential advantage. Many small states have made use of their strategic locations to provide logistical and communications support to the major powers or have played the major powers off against each other. The unique environmental resources of many small island states, 
coupled with improvements in long-distance transport, has made various types of longhaul tourism increasingly attractive and feasible (Dommen, 1980, 1983; Shand, 1980; Wace, 1980; Dommen and Hein, 1985; Armstrong and Read, 1994).

The discussion of international political economy issues highlights the potentially strategic role of international free-riding and rent-seeking in the growth of small states. This is made possible by the policy autonomy of small states which enables them to shape a favourable regulatory and fiscal environment within which they can pursue specialised high value niche activities. International political economy should therefore be regarded as an integral part of the optimal policy portfolio available to small states.

\section{Vulnerability and growth in small states}

A critical implication of the salient economic characteristics of small states is that they have a greater exposure to exogenous shocks than larger states. They are therefore more vulnerable to external economic external economic, strategic and environmental events over which they have little, if any, control (Holmes, 1976; Briguglio, 1995). This has given rise to the Vulnerability Hypothesis, that the long-run growth path of small states is subject to disproportionately greater instability than larger states, while many possess fewer resources to assuage the impact. Small states can therefore be expected to have a lower long-run trend rate of growth than larger states coupled with greater short-run volatility around this trend. The growth and development of small states therefore incurs higher costs and risks because of their size (UNCTAD, 1988) which can only be partially offset by appropriate endogenous strategies. Vulnerability can therefore be regarded as an additional structural characteristic of small states. This Section outlines the potential sources of vulnerability for small states, attempts to develop quantifiable measures of vulnerability and the empirical literature on the impact of vulnerability on the growth of small states.

\subsection{Sources of vulnerability}

The focus of the discussion in Section 2.2 was on the economic aspects of the salient characteristics of small states. In addition to their exposure to sources of economic vulnerability however, small states are also susceptible to additional types of exogenous shocks which also need to be considered in any discussion of vulnerability. The three principal sources of vulnerability are economic, political/strategic and environmental.

\subsubsection{Economic vulnerability}

The economic vulnerability of small states arises primarily as a result of the interaction between the salient characteristics identified in Section 2.2 but especially their high degree of structural openness and import dependence which amplify any external shocks (Holmes, 1976). Small states are especially prone to the destabilising effects of external shocks because of their dependence upon external sources of growth. For island, archipelagic and land-locked small states, this exposure is compounded by their isolation and remoteness which increases transport and communication costs. These costs are not only affected by distance but also by diseconomies and indivisibilities in transport capacity and routings and supply uncertainty. The ability of small states to 
respond effectively to their economic vulnerability is constrained by their limited economic policy autonomy.

\subsubsection{Political and strategic vulnerability}

The political and strategic vulnerability of small states arises because of their susceptibility to external political pressures and strategic manoeuvring by larger neighbouring states and the major powers. This dependent position together with the excessive burden of defence expenditure means that the strategic options available to small states are very limited, including their capacity to maintain their territorial integrity and pursue an independent foreign policy. The strategic vulnerability of smaller states is discussed extensively in the international relations literature, although less attention has been paid to small states in particular (Commonwealth Consultative Group, 1985; Clarke and Payne, 1987).

\subsubsection{Environmental vulnerability}

This encompasses the susceptibility of small states to natural catastrophes, their ecological fragility, the effects of global climate change and the environmental impact of economic development (Beller, d'Ayala and Hein, 1990; Kakazu, 1994; Briguglio, 1995). Natural disasters can have a devastating effect on aggregate GDP, for example the volcanic eruption on Montserrat. Many of these environmental factors are of particular importance to islands and archipelagos in that their unique eco-systems and bio-diversity are highly sensitive to environmental encroachment. Further, low-lying islands are especially vulnerable to the effects of hurricanes and typhoons while global warming and a rising sea-level will affect their long-term habitability.

\subsection{The conceptualisation and measurement of vulnerability}

The analysis of the impact of vulnerability has its origins in the realisation that per capita income-based measures did not adequately reflect the structural and institutional constraints on the growth of small island developing countries. The conceptualisation of vulnerability as an adverse influence on the long-run growth of small (island) states by UNCTAD has led to a number of attempts being made to quantify its impact. Empirical analysis however, is severely constrained by the broad-based nature of vulnerability and problems in defining, identifying and quantifying the components in a robust and meaningful manner.

\subsubsection{The vulnerability index}

The dominant methodology for the measurement and empirical analysis of vulnerability is based on the construction of an index, originally developed by Briguglio (1995). This approach has since been modified and extended, most recently, by the Commonwealth Secretariat (1998-summarised in Easter, 2000) and the United Nations (2000). The index is a weighted composite measure of several critical variables which acts as an adjusted indicator of vulnerability intended to capture the special problems of small states. 
The original Vulnerability Index is based upon three critical sources of vulnerability, small size, insularity/remoteness and susceptibility to natural disaster, measured by openness to trade, the share of transport costs in trade and the cost of natural disasters respectively (Briguglio, 1995). The data is normalised, weighted and converted into an index to create a vulnerability ranking for 114 states. The results suggest that the sample set of small island developing states (SIDS) tend to be more vulnerable than both other developing countries and other countries in general and that a reliance upon GDP per capita data may therefore overstate the economic strength of small states (Briguglio, 1995).

The most recent vulnerability indices are more comprehensive in their methodologies and tend to rely solely upon economic variables. The Commonwealth Vulnerability Index (CVI) uses three vulnerability impact variables significantly related to income volatility, export concentration, export dependence and the effect of natural disasters, together with absolute GDP to measure resilience (Commonwealth Secretariat, 1998). Based upon data for 111 LDCs, the CVI assigns them to one of four broad vulnerability categories. The High Vulnerability category is dominated by states with populations below 2.2 million while the Higher Medium category has only ten states under 2.5 million but includes many larger but relatively poor Sub-Saharan African LDCs. Only four small states feature in the lowest two categories. The UN Economic Vulnerability Index (EVI) is purely an economic index and uses a weighted average of five components; export concentration, export instability, agricultural output instability, share of manufacturing and services in GDP and population size (UN, 2000). Of the 128 LDCs included in the index, some 28 states with populations below 2.9 million are ranked in the 50 most vulnerable states while ten were ranked in the 50 least vulnerable.

\subsubsection{Methodological issues}

There are a number of methodological issues relating to the construction of a robust index capable of capturing the impact of vulnerability effectively (see Read, 2000). The most problematic of these is that the choice of impact vulnerability variables is determined in the first instance by the availability of quantifiable data for a sufficiently large array of countries. Even where data is available, vulnerability indices are likely to be sensitive to the use of alternative variables. The variables in the CVI are determined endogenously according to their effects on income volatility while the EVI uses variables regarded as appropriate economic indicators of development. Islandness is included in the CVI and nearly all the SIDS lie in the High and Higher Medium categories. The EVI ignores islandness such that Fiji, The Maldives and Swaziland (High) and Barbados, Jamaica and Mauritius (High Medium) appear in the 50 least vulnerable states. The EVI therefore tends to rank larger and poorer states as the most vulnerable while the CVI is most concerned with SIDS. The apparently contradictory findings of these two quite sophisticated, but very different, vulnerability indices demonstrate the sensitivity of the results to the choice of impact variables.

All composite indices are likely to be extremely sensitive to the individual weights attached to components. Briguglio's original Vulnerability Index was dominated by the trade openness variable which comprised $50 \%$ of the total weight. In the EVI, all five impact variables are assigned an equal weight. The CVI however, avoids this problem by endogenising the weights within the estimation procedure. 
Any statistical analysis of LDCs and, in particular, small developing states is fraught with difficulty because of the lack of extensive and appropriately comprehensive data. This problem is particularly acute in the case of the smallest states, many of which lack sufficient resources to produce extensive economic and social data. These states therefore tend to be excluded from statistical analyses, resulting in sample selection bias favouring larger states (discussed in Armstrong et al, 1998) although this can be partly resolved by stratifying the data. All of the main vulnerability indices omit the smallest states, notably those in the Pacific, but the CVI also introduces further sample selection bias by endogenising the choice and weights of its impact variables.

A final issue relates to the explanatory power of vulnerability indices and whether they provide additional and relevant information in a manner that is easily comprehended and of use to policy-makers. To date, the principal methodological issues remain unresolved and the conflicting results of the main indices suggest that some degree of consensus concerning the critical impact variables is required. While it is clear that LLDCs and other small developing economies are generally found to be the most vulnerable, the underlying principle of the Vulnerability Hypothesis still awaits statistical confirmation.

\subsection{The impact of vulnerability on the growth in small states}

The exposure of any economy to external shocks has a dampening effect on its long-run growth path and increases instability around the underlying average trend rate of growth. The key premise of the Vulnerability Hypothesis is that the long-run growth of small states is adversely affected by their greater exposure to exogenous shocks, compounded by the lack of resources in many developing small states to fully assuage the impact of this volatility. Small states are therefore likely to experience lower longrun average rates growth characterised by greater amplitudes of fluctuation than larger states. While relatively wealthy small states can be expected to be better able to cope with such volatility, they may be exposed to much greater instability because of their greater dependence upon trade.

As a long-run phenomenon, the empirical veracity of the vulnerability hypothesis can be tested by including vulnerability as an additional conditioning variable in a neo-classical conditional convergence growth model. Using Briguglio's Vulnerability Index results for a limited number of small states, the vulnerability coefficient is found to be positive and significantly related to growth contrary to a priori expectations (Armstrong and Read, 1998c). The most compelling explanation for this counter intuitive result is the mis-specification of the external dependence variable which uses openness to trade as a proxy and its dominant weighting. The apparently paradoxical growth result therefore provides further support for the beneficial role of openness in growth. The impact of vulnerability itself however, remains to be verified satisfactorily.

The Vulnerability Hypothesis represents an important extension to the theoretical literature on small states by incorporating the impact of exogenous shocks in a testable manner. In spite of a priori theorising however, the quantification of vulnerability has been fraught with methodological difficulties such that convincing empirical support for the hypothesis remains lacking. One particular conceptual difficulty with vulnerability is that, because it affects all small states, whether measured according to population 
and/or absolute GDP/GNP, the literature tends to adopt a fatalistic tone. The relative growth success of many states with small populations however, suggests that the impact of vulnerability is uneven. Even normalising for structural openness, location, isolation and predisposition to natural catastrophe, inferences from Section 3.5 suggests that the impact of vulnerability may also be explained by the use of endogenous policies to at least partially offset the adverse effects of small size and therefore vulnerability. Insights from the export instability literature (MacBean, 1966; MacBean and Nguyen, 1987) are supported by the impact of vulnerability and growth experience of relatively diversified small states in the UNCTAD structural typology (UNCTAD, 1997). The critical determinants of growth success therefore appear to lie in effective endogenous policy-making in support of the pursuit of niche export strategies, openness to trade, and international free-riding and rent-seeking. A final, but nevertheless important, point relates to the a priori expectation that vulnerability is inversely correlated with per capita income levels. Growth success in small states increases the degree of exposure to and dependence upon the international economy such that their apparent vulnerability may in fact be greater. It is evident that a number of issues relating to vulnerability therefore still need to be resolved before its implications can be fully understood.

\section{Summary and conclusions: small states and the impact of globalisation}

The primary concern of this paper is growth, economic development and structural transition in small states. While there is some confusion in the literature as to how small size may be defined, this paper utilises low population size together with low absolute GDP/GNP as a reference. The importance of economic, as opposed to political, sovereignty highlights the potential insights to be derived from the additional inclusion of relatively autonomous territorial entities. The discussion of the salient characteristics of small size applies to most, but not all, LDCs as well as those states with populations below 3 million and highlights the implications of economic sub-optimality and its adverse implications for growth. Many small states with low populations however, have been relatively successful in achieving sustained economic growth and improved levels of per capita income. Explanations for this surprising growth performance focus on the critical role of several factors, namely openness to trade, sectoral specialisation in accord with their narrow comparative advantage, location within particular global regions and the effective use of endogenous policies to promote growth, including freeriding and rent-seeking in the international economy. The final section focuses on vulnerability and the increasing interest in the theoretical and empirical literature concerning its implications for the growth of small states, particularly SIDS. The concept of vulnerability captures the disproportionate long-run exposure of small states to a wide range of exogenous shocks and, as such, can be incorporated as an additional conditioning variable in standard growth models. Methodological and data problems however, means that there is as yet little empirical support for the Vulnerability Hypothesis.

It is evident that small states are likely to be extremely sensitive to the impact of globalisation because of the interaction between their high degree of integration in the international economy and their inherent vulnerability. Although small states might be expected to be major beneficiaries of global trade liberalisation, their narrow specialisation and heavy export dependence makes them highly susceptible to adverse changes affecting specific categories of goods and services subject to protectionist 
pressures in both developed and developing countries (Armstrong and Read, 1998). The process of globalisation has accelerated the move towards creating a level international playing field based upon comparative advantage and real competitiveness. This constitutes a severe threat to the continued prosperity of successful small states reliant upon niche market strategies aided by international free-riding and rent-seeking. Perhaps the most important current example of this trend is the action being taken by the OECD and EU against the offshore financial centres to be found in many successful small states. Further, this also suggests that it will be increasing difficult for small developing states to foster similar successful growth strategies in such an environment.

\section{References}

Abbott, G.C. (1975). 'Small states: the paradox of their existence', in P. Selwyn (ed.), Development Policy in Small Countries, Beckenham: Croom Helm, pp 105-14.

Ahlburg, D. (1986). 'Population and economic development in the island nations of the South Pacific', in Cole, R.V. and T.G. Parry (eds), Selected Issues in Pacific Island Development, Canberra: National Centre for Development Studies, Policy Papers, no 2, pp 21-70.

Ally, A. (1975). 'The potential for autonomous monetary policy in small developing countries', in P. Selwyn (ed.), Development Policy in Small Countries, Beckenham: Croom Helm, pp 115-33.

Armstrong, H.W., G. Johnes, J. Johnes and A.I. MacBean (1993). 'The role of transport costs as a determinant of price level between the Isle of Man and the United Kingdom, 1989', World Development, vol 21 (2) pp 311-8.

Armstrong, H.W., R. Jouan de Kervenoael, X. Li and R. Read (1996). The Economic Performance of Micro-States, Report to UK ODA.

Armstrong, H.W., R. Jouan de Kervenoael, X. Li and R. Read (1998). 'A comparison of the economic performance of different micro-states and between micro-states and larger countries', World Development, vol 26 (4) pp 539-56.

Armstrong, H.W., and R.Read (1994). 'Micro-states, autonomous regions and the European Union', European Urban and Regional Studies, vol 1 (1) pp 71-8.

Armstrong, H.W. and R. Read (1995). 'Western European micro-states and EU autonomous regions: the advantages of size and sovereignty', World Development, vol 23 (8) pp 1229-45.

Armstrong, H.W., and R.Read (1998), 'Trade and growth in small states: the impact of global trade liberalisation', World Economy, vol 21 (4) pp 563-85.

Armstrong, H.W., and R. Read (1998a). 'Trade, competition and market structure in small states: the role of contestability', Bank of Valletta Review, no 18, pp 1-18, December.

Armstrong, H.W., and R. Read (1998b). 'The Asymmetric Effects of Economic Integration: Small States and the Formation of Regional Trading Blocs', paper presented at the CRIE Regional Bloc Formation and LDC Trade Conference, Middlesex University, 9th July. 
Armstrong, H.W. and R. Read (1998c). 'The Phantom of Liberty: Economic Growth and the Vulnerability Of Micro-States', Mimeo.

Armstrong, H.W. and R. Read (1999). 'The international political economy of microstates: an overview of the issues', paper presented at the IESG International Political Economy Conference, University of Warwick, 15th and 16th April. Forthcoming in S.M. Murshed (ed.), Issues in Positive Political Economy, Routledge 2001/2.

Armstrong, H.W. and R. Read (2000). 'Comparing the economic performance of dependent territories and sovereign micro-states', Economic Development and Cultural Change, vol 48 (2) pp 285-306.

Armstrong, H.W. and R. Read (2001). 'Explaining differences in the economic performance of micro-states in Africa and Asia', in P. Lawrence and C. Thirtle (eds), Africa and Asia in Comparative Development, Basingstoke: Palgrave.

Ashoff, G. (1989). Economic and Industrial Development Options for Small Third World Countries, Occasional Paper No 91, Berlin: German Development Institute.

Auty, R. (1993). Sustaining Development in Mineral Economics: the Resource Curse Thesis, London: Routledge.

Balassa, B. (1962). Theory of Economic Integration, Baltimore: Johns Hopkins University Press.

Barro, R.J. (1991). 'Economic growth across a cross-section of countries', Quarterly Journal of Economics, no 196, pp 407-33.

Barro, R.J. and X. Sala-i-Martin (1991). 'Convergence across states and regions', Brookings Institute Papers, vol 1, pp 107-82.

Barro, R.J. and X. Sala-i-Martin (1992). 'Convergence', Journal of Political Economy, no 100, pp 223-51.

Bartmann, J.B. and C. Tyrell (1998). 'Lessons from the Edge', paper presented at the ISISA Conference, Islands of the World V, Mauritius, 1st to 5th July, Mimeo.

Bartmann, J.B. (1999). 'Weighing the Options: Sovereignty as a Constitutional Choice for Very Small Territories', paper presented at the Microstates '99 Conference, Globalisation and Constitutionalism, Torshavn, Faroe Islands, 26th-29th April.

Beller, W.P., P. d'Ayala and P.L. Hein (eds) (1990). Sustainable Development and Environmental Management of Small Islands, Paris: UNESCO.

Benedict, B. (1967). 'Introduction' in B. Benedict (ed.), Problems of Smaller Territories, London: Athlone Press, pp 1-18.

Bhaduri, A., A. Mukherji and R. Sengupta (1982). 'Problems of long-term growth in small economies: a theoretical analysis', in B. Jalan (ed.), Problems and Policies in Small Economies, Beckenham: Croom Helm for the Commonwealth Secretariat, pp 49-68.

Blazic-Metner, B. and H. Hughes (1982). 'Growth experience of small economies', in B. Jalan (ed.), Problems and Policies in Small Economies, Beckenham: Croom Helm for the Commonwealth Secretariat, pp 85-101.

Blood, H. (1958). The Smaller Territories, London: Conservative and Unionist Party. 
Briguglio, L. (1995). 'Small island developing states and their economic vulnerabilities', World Development, vol 23 (10) pp 1615-32.

Brookfield, H.C. (1975). 'Multum in parvo: questions about diversity and diversification in small developing countries', in P. Selwyn (ed.), Development Policy in Small Countries, Beckenham: Croom Helm, pp 54-76.

Brookfield, H.C. (1990). 'An approach to islands', in W. Beller, P. d'Ayala and P. Hein (eds) (1990). Sustainable Development and Environmental Management of Small Islands, Paris: UNESCO, Man and the Biosphere Series, vol 5, pp 23-33.

Caldwell, J.C., G.E. Harrison and P. Quiggin (1980). 'The demography of micro states', in R.T. Shand (ed.), The Island States of the Pacific and Indian Oceans: Anatomy of Development, Canberra: Australian National University, Development Studies Centre Monograph 23, pp 121-43.

Chadha, J. (1998). 'Some Observations on Small-State Choice of Exchange Rate Regime', revised version of a paper presented at the IESG Small States in the International Economy Conference, University of Birmingham, 16th and 17th April, mimeo.

Chenery, H.B., S. Robinson and M. Syrquin (1986). Industrialisation and Growth: a Comparative Study, Oxford: Oxford University Press.

Chenery, H.B. and M. Syrquin (1975). Patterns of Development: 1950-1970, Oxford: Oxford University Press.

Chenery, H.B. and L. Taylor (1968). 'Development patterns: among countries and over time', Review of Economics and Statistics, vol 50 (4) pp 391-416.

Clarke, C. and T. Payne (eds) (1987). Politics, Security and Development in Small States, London: Unwin Hyman.

Commonwealth Consultative Group (1985). Vulnerability: Small States in the Global Society, London: Commonwealth Secretariat.

Commonwealth Secretariat (1998). A Study on the Vulnerability of Developing and Island States: a Composite Index, Final Report, presented at the FCO Islands and Small States Conference, Wilton Park, 26-28th February. Mimeo.

Corden, W.M. and P. Neary (1982). 'Booming sector and deindustrialisation in a small open economy', Economic Journal, vol 92 (4) pp 825-48.

de Smith, S.A. (1970). Microstates and Micronesia: Problems of America's Pacific islands and Other Minute Territories, New York: New York University Press.

Demas, W.G. (1965). The Economics of Development in Small Countries: With Special Reference to the Caribbean, Montreal: McGill University Press.

Dolman, A.J. (1985). 'Paradise lost? the past performance and future prospects of small island developing countries', in E.C. Dommen and P.L. Hein (eds), States, Microstates and Islands, London: Croom Helm, pp 40-69.

Dommen, E.C. (1980). 'Some distinguishing characteristics of island states', World Development, vol 8 (12) pp 931-43. 
Dommen, E.C. (1983). 'Invisible Exports From Islands', UNCTAD Discussion Paper, no 9.

Dommen, E.C. (1985). 'What is a micro-state?', in E.C. Dommen and P.L. Hein (eds), States, Microstates and Islands, London: Croom Helm, pp 1-15.

Dommen, E.C. and P.L. Hein (1985). 'Foreign trade in goods and services: the dominant activity of small island economies', in E.C. Dommen and P.L. Hein (eds), States, Microstates and Islands, London: Croom Helm, pp 152-84.

Downes, A.S. (1988). 'On the statistical measurement of smallness: a principal component measure of country size', Social and Economic Studies, vol 37 (3) 75-96.

Easter, C. (1999). 'Small states development: a Commonwealth vulnerability index', The Round Table, no 351, pp 403-22.

Edwards, S. (1993). 'Openness, trade liberalisation and growth in developing countries', Journal of Economic Literature, vol 31 (3), pp 1358-93.

Erbo, G.F. and S Schiavo-Campo (1969). 'Export stability level of development', Bulletin of Oxford Institute of Economics and Statistics, vol 31 (4) pp 263-83.

Graham, F. (1923). 'The theory of international values re-examined', Quarterly Journal of Economics, vol 37, reprinted in H. Ellis and L.S. Meltzer (eds), (1961). Readings in the Theory of International Economics.

Hein, P.L. (1985). 'The study of micro-states', in E.C. Dommen and P.L. Hein (eds), States, Microstates and Islands, London: Croom Helm, pp 16-29.

Helleiner, G.K. (1982). 'Balance of payments problems and macro-economic policy', in B. Jalan (ed.), Problems and Policies in Small Economies, Beckenham: Croom Helm for the Commonwealth Secretariat, pp 165-84.

Holmes, F. (1976). 'Development problems of small countries', in L.V. Castle and F. Holmes (eds), Co-operation and Development in the Asia Pacific Region: Relations Between Large and Small Countries, Tokyo: Japan Research Center, pp 43-66.

Jalan, B. (1982). 'Classification of economies by size', in B. Jalan (ed.), Problems and Policies in Small Economies, Beckenham: Croom Helm, pp 39-47.

Jalan, B. (ed.) (1982a). Problems and Policies in Small Economies, Beckenham: Croom Helm.

Kakazu, H. (1994). Sustainable Development of Small Island Economies, New York: Westview Press.

Keen, M. (1996). 'Tax Competition', paper presented at the Effects of Economic Globalisation and Regional Integration on Small Countries Conference, Nicosia, 4th6th September.

Khalaf, N.G. (1971). Economic Implications of the Size of Nations: With Special Reference to Lebanon, Leiden: EJ Brill.

Khatkhate, D.R. and B.K. Short (1980). 'Monetary and central banking problems of mini-states', World Development, vol 8 (12) pp 1017-26. 
Knox, A.D. (1967). 'Some economic problems of small countries', in B. Benedict (ed.), Problems of Smaller Territories, London: Athlone Press, pp 35-45.

Kohr, L. (1957). The Breakdown of Nations, London: Routledge and Kegan Paul.

Kuznets, S. (1960). 'The economic growth of small nations', in E.A.G. Robinson (ed.), The Economic Consequences of the Size of Nations, London: Macmillan, pp 14-32.

Kuznets, S. (1971). Economic Growth of Nations: Total Output and Production Structure, Cambridge Mass: Belknap.

Labour Party, The (1957). Labour's Colonial Policy, Volume 3: The Smaller Territories, London: The Labour Party.

Lewis, W.A. (1954). Growth and Development, Oxford: OUP.

Lloyd, P.J. and R.M. Sundrum (1982). 'Characteristics of small economies', in B. Jalan (ed.), Problems and Policies in Small Economies, Beckenham: Croom Helm, pp 1738.

MacBean, A.I. (1966). Export Instability and Economic Development, London: George Allen and Unwin.

MacBean, A.I. and D.T. Nguyen (1987). Commodity Problems, Prospects and Policies, London: Croom Helm.

McCall, G. (1996). 'The Study of Islands: Nissology', paper presented at the conference, The Effects of Economic Globalisation and Regional Integration on Small Countries, Nicosia, 4th-6th September, mimeo.

Marcy, G. (1960). 'How far can foreign trade and customs agreements confer upon small nations the advantages of larger nations?', in E.A.G. Robinson (ed.), The Economic Consequences of the Size of Nations, London: Macmillan, pp 265-81.

Milner, C.R. and T. Westaway (1993). 'Country size and the medium-term growth process: some cross-country evidence', World Development, vol 21 (2) pp 203-12.

Pissarides, C.A. (1996). 'Human Development as a Strategic Option for Small Countries', paper presented at the Conference on The Effects of Economic Globalisation and Regional Integration on Small Countries, Nicosia, 6th September.

Pitt, D (1985). 'Anthropological and social theories and micro-states', in E.C. Dommen and P.L. Hein (eds), States, Microstates and Islands, London: Croom Helm, pp 30-9.

Putnam, R.D. with R. Leonardi and R.Y. Nanetti (1993). Making Democracy Work: Civic Traditions in Modern Italy, Princeton: Princeton University Press.

Read, R. (1995). 'Micro-States and Currency Systems: a Review of the Issues and Evidence', paper presented to the IESG Easter Mini-Conference, University of Manchester, 20th-21st April, Mimeo.

Read, R. (2000). 'The Characteristics, Vulnerability and Growth Performance of Small Economies', briefing paper for the WTO Seminar on Small Economies, Palais des Nations, Geneva, 21st October.

Robinson, E.A.G. (ed.) (1960). The Economic Consequences of the Size of Nations, London: Macmillan. 
Rothschild, K.W. (1944). 'The small nation and world trade', Economic Journal, vol LIV, April, pp 26-40.

Rothschild, K.W. (1963). 'Kleinstaat und integration', Weltwirtschaftliches Archiv, vol 90, pp 239-75.

Schaffer, B (1975). 'The politics of dependence', in P Selwyn (ed.), Development Policy in Small Countries, Beckenham: Croom Helm, pp 25-53.

Schumacher, F. (1973). Small is Beautiful, London: Abacus.

Scitovsky, T. (1960). 'International trade and economic integration as a means of overcoming the disadvantages of a small nation', in E.A.G. Robinson (ed.), The Economic Consequences of the Size of Nations, London: Macmillan, pp 282-90.

Selwyn, P. (1975). 'Industrial development in peripheral small countries', in P. Selwyn (ed.), Development Policy in Small Countries, Beckenham: Croom Helm, pp 77-104.

Selwyn, P. (1978). 'Small, Poor and Remote: Islands at a Geographical Disadvantage', University of Sussex, IDS Discussion paper, no 123.

Selwyn, P. (1980). 'Smallness and islandness', World Development, vol 8 (12) pp 94551.

Shand, R.T. (1980). 'Island smallness: some definitions and implications', in R.T. Shand (ed.), The Island States of the Pacific and Indian Oceans: Anatomy of Development, Canberra: Australian National University, Development Studies Centre Monograph 23, pp 3-20.

Smith, T.E. (1967). 'Demographic aspects of smallness', in B. Benedict, (ed.) (1967). Problems of Smaller Territories, London: Athlone Press, pp 11-22.

Srinivasan, T.N. (1986). 'The costs and benefits of being a small, remote, island, landlocked or ministate economy', World Bank Research Observer, vol 1 (2) pp 205-18.

Streeten, P. (1993). 'The special problems of small developing countries,' World Development, vol 21 (2) pp 197-202.

Streeten, P. (1996). 'Why small Countries Succeed', paper presented at the Conference on The Effects of Economic Globalisation and Regional Integration on Small Countries, Nicosia, 4th-6th September, mimeo.

Svennilson, I. (1960). 'The concept of the nation and its relevance to economic analysis', in E.A.G. Robinson (ed.) (1960). The Economic Consequences of the Size of Nations, London: Macmillan, pp 1-13.

Taylor, C. (1969). 'Statistical typology of micro-states and territories: towards a definition of a micro-state', Appendix in UNITAR, Status and Problems of Very Small States and Territories, New York: United Nations. Reprinted as, Small States and Territories: Status and Problems, New York: Arno Press, 1971.

Temple, J. (1999). 'The new growth evidence', Journal of Economic Literature, vol 37 (1) pp 112-56.

Thirlwall, A.P. (1991). The Performance and Prospects of the Pacific Island Economies in the World Economy, East-West Center, Pacific Islands Development Program, Research Report Series, no 14. 
Thomas, I. (1982). 'The industrialisation experience of small economies', in B. Jalan (ed.), Problems and Policies in Small Economies, Beckenham: Croom Helm, pp 10324.

Triffin, R.(1960). 'The size of nation and its vulnerability to economic nationalism', in E.A.G. Robinson (ed.) (1960). The Economic Consequences of the Size of Nations, London: Macmillan, pp 247-64.

UN (2000). 'Committee for Development Policy's economic vulnerability index explanatory note', United Nations CDP2000/PLEN/21.

UNCTAD (1988). Specific Problems of Island Developing Countries, Geneva: UNCTAD.

UNCTAD (1997). The Vulnerability of Small Island Developing States in the Context of Globalization: Common Issues and Remedies, Geneva: UNCTAD, SIDS.

UNIDO(1979). World Industry Since 1961: Progress and Prospects, Vienna: UNIDO.

UNITAR (1969). Status and Problems of Very Small States and Territories, New York: United Nations, republished as, Small States and Territories: Status and Problems, New York: Arno Press, 1971.

Wace, N. (1980). 'Exploitation of some of the advantages of remoteness and isolation in the economic development of Pacific islands', in R.T. Shand (ed.), The Island States of the Pacific and Indian Oceans: Anatomy of Development, Canberra: Australian National University, Development Studies Centre Monograph 23, pp 87-118.

Ward, R.G. (1967). 'The consequences of smallness in Polynesia', in B. Benedict, (ed.) (1967). Problems of Smaller Territories, London: Athlone Press, pp 80-96.

Ward, R.G. (1982). 'The effects of scale on social and economic organisation', in R.J. May and H. Nelson (eds), Melanesia: Beyond Diversity, Canberra: Australian National University, School of Pacific Studies, pp 181-91.

Wood, D.P.J. (1967). 'The smaller territories: some political considerations', in B. Benedict, (ed.) (1967). Problems of Smaller Territories, London: Athlone Press, pp 23-34. 

UNU World Institute for Development Economics Research (UNU/WIDER) was established by the United Nations University as its first research and training centre and started work in Helsinki, Finland in 1985. The purpose of the Institute is to undertake applied research and policy analysis on structural changes affecting the developing and transitional economies, to provide a forum for the advocacy of policies leading to robust, equitable and environmentally sustainable growth, and to promote capacity strengthening and training in the field of economic and social policy making. Its work is carried out by staff researchers and visiting scholars in Helsinki and through networks of collaborating scholars and institutions around the world.

UNU World Institute for Development Economics Research (UNU/WIDER)

Katajanokanlaituri 6 B, 00160 Helsinki, Finland

Camera-ready typescript prepared by Anna Kervinen at UNU/WIDER

Printed at UNU/WIDER, Helsinki

The views expressed in this publication are those of the author(s). Publication does not imply endorsement by the Institute or the United Nations University, nor by the programme/project sponsors, of any of the views expressed.

ISSN 1609-5774

ISBN 952-455-242-6 (printed publication)

ISBN 952-455-243-4 (internet publication) 